\title{
STUDI TENTANG KESIAPAN PENGADILAN AGAMA AMBON KELAS IA TERHADAP PENYELESAIAN SENGKETA PERBANKAN SYARIAH MENURUT UU NO. 3 TAHUN 2006 TENTANG PENGADILAN AGAMA PASCA PENETAPAN UNDANG-UNDANG NOMOR 21 TAHUN 2008 TENTANG PERBANKAN SYARIAH
}

\author{
Hasan, dan Akbar M. Shardi \\ Institut Agama Islam Negeri (IAIN) Ambon \\ Email: hasan.iainamq@gmail.com
}

\begin{abstract}
ABSTRAK
Adapun hasil penelitian, secara esensial pengadilan agama Ambon kelas IA, telah siap dalam rangka menyelesaikan sengketa perbankan syariah terbukti hakim telah meyiapkan diri dengan berbagai cara; sering berdiskusi dengan sesama hakim, mempelajari aturan-aturan terkait dengan ekonomi syariah mislanya; Kompilasi Hukum Islam, Kompilasi Hukum Ekonomi Syariah, Undang-Undang Nomor 21 Tahun 2008 Tentang Perbankan Syariah dan kitab-kitab fiqhi baik itu kitab klasik maupun kitab fikhi kontemporer di satu sisi. Di sisi lain hakim pengadilan agama Kelas IA Ambon berusaha untuk mengikuti program yang dilaksanakan oleh Mahkamah Agung terkait pendidikan dan pelatihan ekonomi syariah namun belum ada yang lulus. Sedangkan pelaksanaan penyelesaian sengketa perbankan syariah belum dijalankan pengadilan agama Ambon kelas IA disebabkan; keadaan kesiapan sumber daya manusia hakim masih kurang memadai, seringnya mutasi hakim di lingkungan pengadilan agama, keengganan masyarakat beperkara di pengadilan agama karena membutukan biaya dan waktu yang banyak, serta kurangnya sosialisasi berbagai ketentuan-ketentuan yang mengatur ekonomi syari'ah atau perbankan syariah kepada masyarakat kota Ambon.

Kata Kunci: Penyelesaian sengketa, Bank Syariah, Pengadilan Agama
\end{abstract}

\begin{abstract}
There is result research, esentially, justices of Ambon's religion Class IA, was ready in order to solve syariah bank dispute evident judge have preparing self variously; often gets discussion with judge humanity, study orders concerning with syariah economic for example; Islamic Law compilation, Jurisdictional compilation of Syariah Economic, UU No. 21 on 2008 About Syariah Bank and fiqhi's books includes classic book and also fikhi kontemporer's book at single-sided. On the other side religion justice judge class IA Ambon tries to follow executed program by Supreme Court concerning education and syariah's economy training but haven't available graduate one. Meanwhile dispute working out performing syariah's bank was carried on Ambon's religion justice Class IA Caused by; human resource of judge preparation situation is still less be equal, occasionally, judge mutation happened in religion justice, troublesome society unwillingness at religion justice because need much cost and time, and its reducing socialization various rule that manage syariah economic or syariah's banking to Ambon's city society.
\end{abstract}

Keyword: solving of dispute, syariah bank, religion justice 


\section{Tahkím}

Vol. XIV, No. 1, Juni 2018

\section{Pendahuluan}

Pembangunan ekonomi suatu Negara memerlukan program yang terencana dan terarah serta membutuhkan modal atau dana pembangunan yang tidak sedikit. Tidaklah mengherankan apabila pemerintah dalam suatu negera terus menerus melakukan upaya peningkatan pertumbuhan ekonomi melalui perbaikan dan peningkatan kinerja bank sebagai lembaga keuangan dan lokomotif pembangunan ekonomi. Lembaga keuangan bank mempunyai peranan yang strategis dalam membangun suatu perekonomian negara. ${ }^{1}$

Bank merupakan lembaga perantara keuangan antara pihak-pihak yang memiliki kelebihan dana dan pihak-pihak yang membutuhkan dana, serta berfungsi untuk memperlancar lalulintas keuangan yang berpijak pada falsafah kepercayaan Bank terdiri dari bank berdasarkan prinsip konvensional dan bank berdasarkan prinsip syari'ah. Fungsi utama bank adalah mempertemukan dua pihak atau lebih yaitu pihak yang membutuhkan dana(borrower) dan pihak yang mempunyai kelebihan dana (saver). ${ }^{2}$

Pemikiran dan kesadaran mengenai perlunya diterapkan system syari'ah di Indonesia berjalan sejak lama. Lokakarya Ulama mengenai Bank dan Bunga Bank di Cisarua pada tanggal 19-23 Agustus 1990 merekomendasikan perlunya mendirikan Bank tanpa bunga. Harapan itu secara yurudis mendapatkan respon melalui UndangUndang Nomor 7 Tahun 1992 tentang Perbankan. Dalam Undang-Undang disebut belum secara tegas "Bank Syari' ah" yang ada sebutan "bank berdasarkan prinsip bagi hasil". Walau demikian atas dukungan Majelis Ulama Indonesia (MUI) dan Cendekiawan Muslim Indonesia (ICMI) termasuk para pengusaha muslim pada tahun 1992 didirikan Bank Muamalat Indonesia (BMI). Secara yuridis, baru di era reformasi dengan Undang-Undang Nomor 10 tahun 1998 sebagai revisi dari Undang-Undang Nomor 7 Tahun 1992, istilah pembiayaan berdasarkan syariah dan prinsip syariah, disebut secara tegas. ${ }^{3}$ Hal tersebut dinyatakan dalam Pasal 1 Ayat (3) dan (4), sehingga secara yuridis, eksistensi dan legitimasi bank Syariah dalam tata hukum perbankan nasional dapat dikatakan sudah lebih jelas dan pasti dibandingkan dengan sebelumnya. Lebih-lebih setelah tertibnya UU No. 23 Tahun 1999 tentang Bank Indonesia, yang sekarang telah diubah dengan Undang-Undang No. 3 Tahun 2004, yang memuat beberapa ketentuan secara spesifik berkaitan langsung dengan eksistensi dan pengembangan perbankan syariah di Indonesia. ${ }^{4}$

${ }^{1}$ Muhammad, Bank Syariah Problem dan Prospekk Perkembangan di Indonesia (Yogyakarta: Graha Ilmu, 2005), h. 1

${ }^{2}$ Krisna Wijaya, Reformasi Perbankan Nasional (Jakarta: Harian Kompas, 2000), h. 46 2005), h. 62

Karnaen Perwataatmadja, Bank dan Suransi Islam di Indonesia (Jakarta: Prenada Media,

${ }^{4}$ Sutan Remy Sjahdeini, Perbankan Islam dan Kedudukannya Dalam Tata Hukum Perbankan Indonesia (Jakarta: Pustaka Utama Grafiti, 1999), h. .xiv 


\section{Tahkím}

Vol. XIV, No. 1, Juni 2018

Upaya untuk melengkapi aturan-aturan hukum mengenai bank syariah yang dilakukan oleh Bank Indonesia (BI) dengan mengeluarkan beberapa Surat Keputusan (SK), sebagai landasan operasional bagi bank syariah. Di antaranya; SK Direksi BI No. 32/34/KEP/DIR tanggal 12 Mei 1999 tentang Bank Umum Berdasarkan Prinsip Syariah, dan SK Direksi BI N0. 32/36/KEP/DIR tanggal 12 Mei 1999 tentang Bank Perkreditan Rakyat Berdasarkan Prinsip Syariah. Kedua SK tersebut kemudian diganti dengan PBI No. 6/17/PBI/2004 tanggal 1 Juli 2004 tentang Bank Perkreditan Rakyat berdasarkan prinsip syariah dan Peraturan Bank Indonesia (PBI) No. 6/24/PBI/2004 tanggal 14 Oktober 2004 tentang Bank Umum yang melaksanakan kegiatan usahanya berdasarkan prinsip syariah. ${ }^{5}$

Sejalan dengan itu, masuknya sengeketa bidang perbankan syariah kedalam kewenangan absolute lingkungan peradilan agama sebagaimana diatur dalam UndangUndang Nomor 3 Tahun 2006 perubahan atas Undang-Undang Nomor 7 Tahun 1989 yang mana sengketa ekonomi syari'ah menjadi wewenang peradilan agama, yang kemudian disusul dengan terbitnya Undang-Undang Nomor 21 Tahun 2008 tentang Perbankan Syariah. Hal ini antara lain dimaksudkan agar prinsip-prinsip syariah yang menjadi landasan hukum bank syariah dalam menjalankan aktivitasnya dapat diterapkan secara optimal, konkrit dan seutuhnya. ${ }^{6}$

Hal tersebut, apabila perkara perbankan syariah tetap menjadi kewenangan peradilan umum, penyelesaiannya jelas tidak akan mengacu pada prinsip-prinsip syariah yang menjadi dasar hukum bank syariah, melainkan akan mengacu pada ketentuanketentuan yang berlaku secara umum yang belum tentu relevan dengan prinsip-prinsip syariah, sedangkan secara konkrit dan seutuhnya, melainkan hanya bersifat konseptual dan parsial saja. Harapannya agar prinsip syariah tersebut dapat diterapkan dan ditegakkan secara konkrit dan seutuhnya dalam sistem operasional bank syariah dan menjadi kewenangan Peradilan Agama. ${ }^{7}$

Dalam rangka merespon hal tersebut, maka diberlakukan asas personalitas keislaman bahwa setiap orang Islam baik secara subjektif mauapun secara objektif berlaku (tunduk pada) hukum Islam, yang kemudian diperkuat dengan putusan Mahkamah Konstitusi Nomor: 93/PUU-X/2012 bahwa sengketa ekonomi syariah atau perbankan syarih dilaksanakan oleh pengadilan agama ${ }^{8}$

\footnotetext{
${ }^{5}$ Cik Basir, Penyelesaian Sengkat Bank Syariah (Jakarta: Kencana 2008), h. 4

${ }^{6}$ M. Syaifi'i Antonio, Bank Syariah Antara Teori Ke Praktek (Jakarta: Gema Insani, 2005), h. 214

${ }^{7}$ Rachmadi Usman, Aspek-aspek Hukum Perbankan di Indonesia (Jakarta: Gramedia Pustaka Utama, 2003), h. 4

${ }^{8}$ A. Mukti Arto, Garis Batas Kekuasaan Pengadilan Agama dan Pengadilan Negeri: Penerapan Asas Personalitas Keislaman Sebagai Dasar Penentuaan Kekuasaan Pengadilan Agama (Jakarta: Varia Peradilan, 2000), h. 21
} 


\section{Tahkim}

Vol. XIV, No. 1, Juni 2018

Olehnya itu, penulis cenderung pada permasalahan bagaimana Studi Tentang Kesiapan Pengadilan Agama Kelas IA Ambon Terhadap Penyelesaian Sengketa Perbankan Syariah Menurut Undang-Undang No. 3 Tahun 2006 Pasca Penetapan UU No. 21 Tahun 2008 Tentang Perbankan Syariah.

\section{Kewenagan Pengadilan Agama dalam penyelesaian sengketa perbankan menurut Undang-Undang Nomor 3 Tahun 2006 dan Undang-Undang Nomor 21 Tahun 2008 Tentang Perbankan Syariah}

Keberadaan lembaga Peradilan Agama di Indonesia tidak dapat dilepaskan dari kebutuhan masyarakat Indonesia yang beragama Islam dalam melaksanakan ajaran agamanya yang berupa hukum Islam. Dalam konsepsi ilmu fikih, masalah peradilan atau al-qadla merupakan kewajiban kolektif atau fardlu kifayah, yang disamakan dengan fardlu kifayah lainnya, seperti mendirikan jamaah dan shalat jumat, mempelajari ilmu dan mengajarkan ilmu (thalabul ilmi wal ifta fi majalisil ilmi), menyelenggarakan kesejahteraan umum dan mencegah kemungkaran (amar ma"ruf nahi mungkar untuk mashalihul ammah) serta mendirikan kepemimpinan umat atau bernegara (al imamah). ${ }^{9}$

Kontroversi sempat muncul dimana Undang-Undang Nomor 21 Tahun 2008 tentang Perbankan Syariah, menimbulkan persoalan baru sebab dalam penjelasan Pasal 55 Ayat (2) mengatur apabila terjadi persengketaan perbankan syariah, selain diselesaikan pengadilan agama, juga dapat diselesaikan melalui pengadilan dalam lingkungan pengadilan umum. ${ }^{10}$

Kemudian penjelasan Pasal 55 Undang-Undang Nomor 21 Tahun 2008 tentang Perbankan Syariah tersebut telah dibatalkan oleh Mahkamah Konstitusi melalui putusan Nomor : 93/PUU-X/2012, sehingga seluruh bentuk akad atau perikatan syariah yang diatur dalam Pasal 49 Undang-Undang Nomor 3 Tahun 2006 jika terjadi sengketa sudah menjadi kewenangan absolut pengadilan agama. Oleh karenanya pihak-pihak yang melakukan akad berdasarkan prinsip-prinsip syariah telah tertutup untuk melakukan pilihan melalui pengadilan di luar pengadilan agama, ${ }^{11}$

Berdasarkan uarain tersebut di atas, maka dapat dikemukakan bahwa batas jangkauan kewenangan mengadili Pengadilan Agama di bidang perbankan syariah antara lain:

${ }^{9}$ H. Zaini Ahmad Noeh, Sejarah Peradilan Agama di Indonesia, (Laporan Hasil Simposium Sejarah Peradilan Agama tanggal 8 s.d. 10 April 1982 di Hotel USSU Cisarua Bogor), Bagian Proyek Pembinaan Administrasi Hukum dan Peradilan Agama, Departemen Agama RI, 1982/1983.

${ }^{10}$ Lihat Republik Indonesia, Undang-Undang Nomor 21 Tahun 2008 tentang Perbankan Syariah, (Bandung: Fokus Media, 2011), h. 101

${ }^{11}$ Ahmad Mujahidin, Prosedur Penyelesaian Sengketa Ekonomi Syariah di Indonesia (Bogor: Ghalia Indonesia, 2010), h. 20 


\section{Tahkím}

Vol. XIV, No. 1, Juni 2018

1. Dua bidang hukum lain yang mengatur tentang aktivitas operasional perbankan syariah yakni hukum pidana dan hukum tata negara merupakan kewenangan absolut Peradilan Umum dan peradilan Tata Usaha Negara. Dengan adanya asas personalitas keislaman yang termuat dalam Undang-Undang Nomor 3 Tahun 2006 Tentang Peradilan Agama maka setiap orang Islam baik secara subjektif maupun secara objektif berlaku (tunduk pada) hukum Islam, sehingga hukum Islam secara imperatif (otomatis) diberlakukan terhadap dirinya, dan karena itu jika terjadi sengketa harus diselesaikan menurut hukum Islam oleh hakim (pengadilan) Islam.

2. Termasuk dalam pengertian asas personalitas keislaman maka, semua badan hukum Islam yang ada dalam sistem hukum di Indonesia termasuk dalam hal ini bank syariah. Terhadap semua badan hukum Islam yang dimaksud baik mengenai status hukumnya maupun mengenai perbuatan atau peristiwa hukum yang menimpanya, juga mengenai hubungan hukum dengan orang atau badan hukum lain serta hak milik badan hukum tersebut, sepanjang berkaitan dengan prinsip-prinsip syariah, harus berlaku (tunduk pada) hukum Islam dan jika terjadi sengketa, harus diselesaikan berdasarkan hukum Islam oleh hakim (pengadilan) Islam.

3. Cakupan kewenangan absolut Pengadilan Agama juga mampu menjangkau seluruh sengketa yang terjadi antara pihak bank dengan nasabah yang non-Islam. Sebagaimana yang diketahui, pihak-pihak yang bertransaksi atau yang menjadi mitra usaha di perbankan syariah tidak hanya pihak yang beragama Islam saja, melainkan juga yang non-Islam sebagaimana dijelaskan dalam Undang - Undang Nomor 3 Tahun 2006 Tentang Perubahan atas Undang-Undang No. 7 Tahun 1989 Tentang Peradilan Agama adalah adanya satu asas penting yang baru diberlakukan yakni asas penundukan diri terhadap hukum Islam, sebagaimana Pasal 49 undangundang tersebut yang dalam penjelasannya "yang dimaksud dengan antara orang orang yang beragama Islam"12.

Berdasarkan pada uraian tersebut di atas, maka dapatlah disimpulkan bahwa pasca penetapan Undang-Undang Nomor 3 Tahun 2006 Tentang Kewenangan Pengadilan Agama dan Udang-Undang Nomor 21 Tahun 2008 Tentang Perbankan Syariah serta ditegaskan dalam keputusan Mahkamah konstitusi Nomor: 93/PUU$\mathrm{X} / 2012$, sehingga seluruh bentuk akad atau perikatan syariah yang diatur dalam Pasal 49 Undang-Undang Nomor 3 Tahun 2006 jika terjadi sengketa sudah menjadi kewenangan absolut pengadilan agama.

${ }^{12}$ Lihat pasal 49 Undang Nomor 3 Tahun 2006 Tentang Perubahan atas Undang - Undang No. 7 Tahun 1989 Tentang Peradilan Agama 


\section{Tahkím}

Vol. XIV, No. 1, Juni 2018

\section{Kesiapan Pengadilan Agama Ambon Terhadap penyelesaian sengketa perbankan syariah menurut UUNo. 3 Tahun 2006 Pasca Penetapan UU No. 21 Tahun 2008 Tentang Perbankan Syariah.}

Berdasarkan observasi lapang dan hasil wawancara peneliti lakukan di pengadilan Agama Klas I A Ambon, bahwa ada beberapa faktor yang berhubungan dengan kesiapan pengadilan agama kelas IA Ambon dalam proses penyelesaian sengketa perbankan syariah, sebagai berikut;

1. Sumber Daya Manuasi (Hakim) Pengadilan Agama Ambon Kelas IA

a. Hakim pengadilan Agama Ambon Kelas IA memiliki kompotemnsi meyelesaikan sengketa perbankan syariah

Sesuai hasil wawancara dengan instrument bagian pertama no. 1 tentang Hakim pengadilan Agama Ambon memiliki kompotensi meyelesaikan sengketa perbankan syariah dengan hakim di Pengadilan Agama Kelas IA Ambon, cukup bervariasi.

Menurut Drs. Salahuddin, SH.MH, bahwa

Hakim di Pengadilan Agama Kelas IA Ambon ini, telah memiliki kompotensi pribadi dalam menyelesaiakan sengketa perbankan syariah berdasarkan pengalaman yang dimiliki dalam menjalankan tugas sebagai hakim yang mana dituntut untuk menguasai kaidah-kaidah fiqhi dalam hal memutuskan suatu perkara. Oleh karenanya maka ketika ada permasalahan yang diajukan ke pengadilan agama kelas IA ambon, secara otomatis dapat diproses dan diselesaiakan dengan dasar-dasar dan ketentuan undang-undang yang berlku, misalnya telah ada Undang-Undang No 21 Tahun 2008 tentang Perbankan Syariah, Kompilasi Hukum Islam dan Kompilasi Hukum Ekonomi Syariah sebagai rujukan. $^{13}$

Berdasarkan hasil wawancara tersebut di atas, maka dapatlah disimpulkan bahwa Hakim pengadilan agama pada dasarnya telah memiliki kompotensi dalam menyelesaikan sengketa perbankan syariah karena hakim pengadilan agama rata-rata memiliki besik pendidikan Islam di satu sisi, di sisi lain bahwa hakim pengadilan agama dalam menjalankan tugasnya sebagai hakim dalam memutuskan suatu perkara selalu berdasarkan kaidah-kaidah fiqhi selain aturan dan yurispunsi sebelumnya.

${ }^{13}$ Drs. Salahuddin, SH.MH, Hakim Pengadilan Agama Ambon Kelas IA, "Hasil Wawancara" Tanggal 2 Agustus 2016 


\section{Tahkím}

Vol. XIV, No. 1, Juni 2018

b. Hakim pengadilan agama Ambon telah memiliki kemampuan akademik dalam proses penyelesaian sengketa perbankan

Adapun kompotensi akademik hakim pengadilan agama Kelas IA Ambon, yang dimiliki belum ada terkait dengan spesifikasi ekonomi syariah, sebagaimana hasil wawancara dengan Drs Dasri Akil, SH dan Dra. Nurhayati Latuconsina, mengemukakan sebagai berikut;

Hakim pengadilan agama Kelas IA Ambon, belum memiliki hakim yang memiliki kompotensi akademik ekonomi syariah, sehingga dalam menyikapi hal tersebut kementerian Hukum dan HAM mengadakan kursus sertifikasi ekonomi syariah selain melanjutkan pendidikan pada jenjang magister. ${ }^{14}$

Hal itu erat kaitannya dengan eksistensi kompetensi pengadilan agama terhadap perkara dimaksud. Berbeda halnya dengan perkara yang selama ini telah menjadi kompetensi pengadilan agama sejak dulu.

Pendapat senada diungkapkan oleh H. Alimin A. Sanggo, SH, dalam wawacara, sebagai berikut;

Bahwa ketika berbicara tentang kompotensi akademik hakim pengadilan agama Kelas IA Ambon terkait dengan penyelesaian sengketa ekonomi syariah dan perbankan syariah, belum ada dengan bukti bahwa belum ada hakim yang memiliki gelar setingkat magister dalam bidang ekonomi syariah. Namun dalam rangka menyikapi hal tersebut maka kementerian Hukum dan HAM mengadakan pendidikan khusus ekonomi syariah kepada hakim pengadilan agama se Indonesia dan sampai saat ini hakim pengadilan agama kelas IA Ambon belum ada yang mengikuti pelatihan tersebut. ${ }^{15}$

Merujuk pada hasil wawancara tersebut, maka dapatlah dipahami bahwa hakim pengadilan Agama Ambon Kelas IA, jika ditinjau dari kemampuan akademiknya sesungghnya belum ada dengan bukti bahwa rara-rata hakim masih strata satu dan jika bergelar magister hanya sebagian saja dan belum ada hakim yang memiliki sertifikat ekonomi syariah dari mahkamah agung.

c. Dalam rangka penyelesaian sengketa perbankan upaya apa yang dilakukam oleh hakim pengadilan Agama Kelas IA Ambon

Sesuai dengan instrument wawancara tentang upaya yang dilakukam oleh hakim pengadilan Agama Kelas IA Ambon dalam proses penyelesaian sengketa perbankan syariah, sebagai berikut;

${ }^{14}$ Drs Dasri Akil, SH dan Dra. Nurhayati Latuconsina, Hakim Pengadilan Agama Ambon Kelas IA, "Hasil Wawancara" Tanggal 1 Agustus 2016

${ }^{15}$ H. Alimin A. Sanggo, SH, Hakim Pengadilan Agama Ambon Kelas IA, "Hasil Wawancara" Tanggal 3 Agustus 2016 


\section{Tahkím}

Vol. XIV, No. 1, Juni 2018

Hal tersebut, Sebagaimana dikemukakan oleh Drs. H.Ediwarman.SH.MHI, dalam hasil wawancara, sebagai berikut;

Upaya hakim pengadilan Agama Kelas IA Ambon dalam rangka menyelesaikan sengketa perbankan syariah dengan meyiapkan diri, sering berdiskusi dengan sesama hakim, mempelajari aturan-aturan terkait dengan ekonomi syariah mislanya; Kompilasi Hukum Islam, Kompilasi Hukum Ekonomi Syariah, UndangUndang Nomor 21 Tahun 2008 Tentang Perbankan Syariah. Selain hal tersebut sesungguhnya yang menjadi dasar pertimbangan hakim pengadilan agama adalah kitab-kitab fiqhi baik itu kitab klasik maupun kitab fikhi kontemporer, sehingga jika ada masyarakat yang bekepentingan mengajukan permohonana penyelesaian sengketa perbankan syariah dapat diselesaiakan di pengadilan agama kelas IA Ambon. ${ }^{16}$

Merujuk pada uaraian hasil wawancara tersebut di atas, maka dapatlah diungkapkan, bahwa jika ada kasus yang diajikan di pengadilan agama ambon kelas IA, maka upaya para hakim untuk menambah pengetahuannya dalam rangka memutuskan perkara dengan mempelajari kitab-kitab fiqhi baik klasik maupun kontemporer, kompilasi hukum Islam, Undang-Undang no 21 Tahun 2008 tentang perbankan syariah dan kompilasi hukum ekonomi syariah serta putusan-putusan hakim pengadilan agama wilayah lain di Indonesia.

d. Respon hakim pengadilan Agama kelas IA Ambon dalam menyikapi kewenagan pengadilan agama dalam penyelesaian sengketa pasca penetapan UU No 3 Tahun 2003 tentang kewenagan Absolut Pengadilan Agama dan UU No 21 Tahun 2008 tentang perbakan Syariah.

Hal tersebut, sebagaimana hasil wawancara dengan Drs Dasri Akil, SH, sebagai berikut;

Perluasan kewenangan pengadilan Agama tentang ekonomi Syari'ah atau perbankan syariah membuat kami hakim pengadilan Agama kelas IA Ambon lebih belajar lagi baik dari buku, web resmi mahkamah agung, maupun penelitian tentang ekonomi Syari'ah. tidak menutup kemungkinan untuk kita berdiskusi tentang ekonomi Syari'ah. kami juga berupaya mengikuti pelatihan tentang ekonomi Syari' ah yang diadakan oleh Mahkamah Agung, namun sampai saat ini belum ada yang berhasil untuk mengikuti pelatihan tersebut. ${ }^{17}$

Berdasarkan hasil wawancara tersebut di atas, maka dapatlah dipahami bahwa para hakim pengadilan Agama Kelas IA Ambon dalam rangka menyelesaikan sengketa

\footnotetext{
${ }^{16}$ Drs. H.Ediwarman.SH.MHI, Ketua Pengadilan Agama Ambon Kelas IA, "Hasil Wawancara" Tanggal 1 Agustus 2016

${ }^{17}$ Drs Drs Dasri Akil, SH, Hakim Pengadilan Agama Ambon Kelas IA, "Hasil Wawancara" Tanggal 1 Agustus 2016
} 


\section{Tahkím}

Vol. XIV, No. 1, Juni 2018

perbankan syariah dengan meyiapkan diri dengan berbagai cara, sering berdiskusi dengan sesama hakim, mempelajari aturan-aturan terkait dengan ekonomi syariah mislanya; Kompilasi Hukum Islam, Kompilasi Hukum Ekonomi Syariah, UndangUndang No 21 Tahun 2008 Tentang Perbankan Syariah dan kitab-kitab fiqhi baik itu kitab klasik maupun kitab fikhi kontemporer di satu sisi. Di sisi lain hakim pengadilan agama Kelas IA Ambon berusaha untuk mengikuti program yang dilaksanakan oleh Mahkamah Agung terkait pendidikan dan pelatihan ekonomi syariah, namun hakim pengadilan agama Kelas IA Ambon belum ada yang lulus untuk mengikuti pendidikan tersebut.

\section{Infrastruktur}

a. Pasca penetapan UU No 3 Tahun 2003 dan UU No 21 Tahun 2008 tentang perbakan Syariah, apakah pengadilan agama Ambon telah mempersiapkan infrastruktur dalam proses penyelesaian sengketa perbankan syariah

Sesuai dengan instrument tentang infrastruktur penyelesaian sengketa perbankan syariah pada pengadilan agama kelas IA Ambon, sebagaimana dikemukakan oleh Drs. H.Ediwarman,SH.MHI dalam wawancara, sebagai berikut;

Dipengadilan agama Kelas IA Ambon smpai saat ini belum ada infrastruktur yang disiapakan dalam rangka meyelesaikan sengketa ekonomi syariah atau perbankan syariah disebabkan belum ada yang mengajukan kasus sengketa ekonomi syariah atau perbankan syariah di satu sisi, di sisi lain faktor pengadilan agama sendiri yang belum menyiapkan hal tersebut, walaupun sebenarnya telah diamanatkan dalam Undang-Undang No 3 Tahun 2006 Tentang Kewenangan pengadilan Agama. ${ }^{18}$

Berdasarkan hasil wawancara tersebut di atas, maka dapatlah dipahami bahwa sesuai amanat undang-undang no 3 tahun 2006 tentang kewennagan absolute pengadilan agama, maka seharusnya setiap pengadilan agama menyediakan infrastruktur dan majelis dalam rangka menyelesaikan sengketa ekonomi syariah atau sengketa perbankan syariah, namun pada pengadilan agama ambon kelas IA belum ada.

b. Dalam proses penyelesaian sengketa perbankan syariah, apakah ada perbedaan dengan proses persidangan perceraian

Sesuai dengan instrument tentang perbedaan proses penyelesaian sengketa perbankan syariah dengan proses persidangan perceraian, sebagaimana hasil wawancara yang dikemukakan oleh Drs. Abd. Razak Payapo, sebagai berikut;

Tentunya proses penyelesaian sengketa perbankan syariah memiki perbedaan dengan proses persidangan penyelesaian perceraian, sehingga terkait dengan penyelesaain sengketa ekonomi syariah atau sengketa perbankan ayariah harus

${ }^{18}$ Drs. H.Ediwarman.SH.MHI, Ketua Pengadilan Agama Ambon Kelas IA, "Hasil Wawancara" Tanggal 1 Agustus 2016 


\section{Tahkím}

Vol. XIV, No. 1, Juni 2018

diadakan majelis khusus dan diharuskan ada yang telah memiliki sertifikat pelatihan menyelesaikan sengketa ekonomi Syari'ah yang diadakan oleh Mahkamah Agung. Pengadilan Agama Kelas IA Ambon dalam hal ini belum memiliki hakim yang memiliki setifikat pelatihan ekonomi syariah. ${ }^{19}$

Sejalan dengan hasil wawancara tersebut, maka dapatlah dipahami bahwa dalam rangka penyelesaian sengketa perbankan syariah memiliki perbedaan dengan persidangan kasus perceraian yang mana dalam hal tersebut diharuskan memiliki majelis khusus untuk menyelesaikannya dengan persyaratannya hakim yang memahami dan mengerti sekaligus diwajibkan memiliki sertifikat pelatihan ekonomi syariah, selain harus memiliki kompotensi khusus terkait dengan ekonomi syariah atau perbankan syariah

c. Penyebab pengadilan agama kelas IA Ambon belum mempersiapkan majelis persidangan ekonomi syariah atau perbankan syariah.

Merujuk pada instrumen wawancara penyebab pengadilan agama kelas IA Ambon belum mempersiapkan majelis persidangan ekonomi syariah atau perbankan syariah, maka dapat dijelaskan berdasarkan hasil wawancara dengan hakim ketua pengadilan agama kelas IA Ambon, Drs. H. Ediwarman.SH.MHI, sebagaimana hasil wawancara sebagai berikut;

Sebenarnya pengadilan agama kelas IA Ambon, telah merespon semua hal tersebut namun sampai saat ini belum ada pengajuan dari masyararakat terkait dengan sengketa ekonomi syariah atau perbankan syariah, sehingga majelis hakim dan infrastrukturnya pun belum disiapkan. Akan tetapi apapun alasannya pengadilan agama kelas IA Ambon akan tetap mempersiapkan diri dalam rangka menjalankan hal tersebut dengan bukti para hakim dianjurkan untuk mengikuti tes seleksi peserta pelatihan ekonomi syariah yang walaupun belum ada yang lulus untuk mengkuti pelatihan tersebut. $^{20}$

Hasil wawancara tersebut, menunjukkan, bahwa sebab-sebab majelis khusus meyelesaikan sengketa ekonomi syariah atau perbankan syariah belum diadakan baik itu infra strukturnya maupun majelis hakimnya di pengadilan agama kelas IA Ambon karena tidak adanya pengajuan kasus dari masyarakat dan belum ada hakim pengadilan agama kelas IA Ambin yang memiliki sertifikat ekonomi syariah dan belum ada hakim yang memiliki kompotensi atau gelas akademik khusus ekonomi syariah.

${ }^{19}$ Drs. Abd. Razak Payapo, Hakim Pengadilan Agama Ambon Kelas IA, "Hasil Wawancara" Tanggal 4 Agustus 2016

${ }^{20}$ Drs. H.Ediwarman.SH.MHI, Ketua Pengadilan Agama Ambon Kelas IA, "Hasil Wawancara" Tanggal 1 Agustus 2016 


\section{Tahkim}

Vol. XIV, No. 1, Juni 2018

\section{Pengetahuan Masyarakat}

Sesuai dengan instrument pengetahuan masyarakat tentang penyelesaian ekonomi syariah atau perbankan syariah pada pengadilan agama kelas IA Ambon, sebagai berikut;

a. Pengeatahuan masyarakat tentang pennyelesaian perbankan syariah sesuai UU No 3 Tahun 2006 tentang kewenangan pengadilan Agama.

Berdasarkan instrument tersebut sebagaimana keterangan yang dikemukakan oleh H. Alimin A. Sanggo, SH dalam wawancara, sebagai berikut;

Sesungguhnya masyarakat belum mengetahui secara pasti mengenai UU No 3 Tahun 2006 tentang kewenangan absolute pengadilan Agama, yang mana dijelaskan didalamnya bahwa sengketa ekonomi syariah atau perbankan syariah sudah menjadi kewenagan dari pengadilan agama. Hal tersebut sebagaimana dapat dibuktikan dengan msyarakat tidak mengajukan permasalahan sengketa perbankan walaupun di ambon telah banyak beropersi perbankan syariah. ${ }^{21}$

Merujuk dari hasil wawancara tersebut di atas menunjukan, bahwa masyarakat kota Ambon belum mengetahui secara pasti mengenai UU No 3 Tahun 2006 tentang kewenangan absolute pengadilan Agama, sehingga dalam pelaksanaannya terkait dengan sengketa perbankan syariah sampai saat belum ada yang diajukan dan diselesaiakn di pengadilan agama Ambon kelas IA. Hal tersebut merupakan suatu realitas dan menjadi tanggungjawa pengadilan agama dan instansi terkait untuk mensoasialisaikannya sehingga dapat dimengerti dan diaplikasikan.

b. Jika ada sosialisasi yang dilkukakan oleh hakim pengadilan agama Ambon, bagaimana pandangan masyarakat tentang hal tersebut

Berdasarkan instrument tersebut sebagaimana keterangan yang dikemukakan oleh Drs Dasri Akil, SH dalam wawancara, sebagai berikut;

Mengenai upaya pengadilan agama mensosialisasikan UU No 3 Tahun 2006 tentang kewenangan absolute pengadilan Agama, kepada masyarakat, seharusnya pengadilan agama melaksanakannya namun karena keterbatasan anggaran mengenaihal tersebut maka pengadilan agama Ambon kelas IA tidak melasksanakannya. Hal tersebut dengan alasan bahwa kegiatan tersebut seharusnya dimasukkan dalam kegiatan bimbingan teknis namun hal tersebut juga telah dihapus. ${ }^{22}$

\footnotetext{
${ }^{21}$ H. Alimin A. Sanggo, SH, Hakim Pengadilan Agama Ambon Kelas IA, "Hasil Wawancara" Tanggal 3 Agustus 2016

${ }^{22}$ Drs Dasri Akil, SH, Hakim Pengadilan Agama Ambon Kelas IA, "Hasil Wawancara" Tanggal 1 Agustus 2016
} 


\section{Tahkím}

Vol. XIV, No. 1, Juni 2018

Dari hasil wawncara tersebut di atas, maka dapatlah disimpulkan bahwa pengadilan agama Ambon kelas IA, sebenarnya berupaya semaksimal mungkin dalam rangka mensosialisasikan perlusan kewenangan pengadilan agama sesuai amant UU No 3 Tahun 2006 tentang kewenangan absolute pengadilan Agama, namun dengan peniadaan program, seperti bimbingan kepada masyarakat sehingga para hakim terasa pesismis untuk melaksanakan hal tersut.

c. Jika tetap ada masyarakat yang menyampaikan persoalan terkait dengan sengketa perbankan syariah, apa yang diupayakan oleh pengadilan agama untuk dapat melaksanakan tugasnya.

Berdasarkan instrument tersebut sebagaimana keterangan yang dikemukakan oleh Drs. Salahuddin, SH.MH dalam wawancara, sebagai berikut;

Pada dasarnya hakim pengadilan bersikap pasif, dalam artian jika ada pengaduan dari masyarakat maka diupayakan agar kasus tersebut untuk diselesaikan. Namun jika tidak ada pengajuan kasus dari masyarakakat, maka tidak ada jalan lain selain hakim hanya menunggu di satu sisi, di sisi lain hakim tidak ada upaya lain untuk memberikan pemahaman kepada masyarakat karena saat ini tidak ada program untuk mensosialisasikan hal tersebut kepada masyarakat. ${ }^{23}$

Merujuk pada uraian wawancara tersebut di atas, maka dapatlah disimpulkan bahwa masih kurangnya pemahaman masyarakat kota Ambon tentang sengketa perbankan syariah telah menjadi kewenangan pengadilan agama. Hal tersebut terjadi disebabkan kurangnya upaya pengadilan agama untuk memberikan pemahaman terhadap masyarakat. Hal lain karena pelaku usaha dalam bidang perbankan syariah kurang mengalami kendala, atau boleh jadi bahwa penyelesaian sengketa tersebut diselesaikan secara non litigasi berdasarkan isi perjanjian yang telah disepakati sejak awal.

Pesatnya perkembangan bisnis berbasis pada ekonomi syariah yang sejalan dengan perluasan kewenangan pengadilan agama untuk menangani sengketa ekonomi syariah, tentu akan memberi konsekuensi tersendiri bagi pengadilan agama, sehingga harus memiliki hakim-hakim khusus yang kapabel dalam menangani sengketa ekonomi syariah, para hakim juga dituntut lebih responsif terhadap perkembangan managemen peradilan yang lebih modern. Bahkan seorang hakim pengadilan agama dalam hal kesiapan mengadili sengketa ekonomi syariah akan dihadapkan dengan tantangan terbesar dalam menghadapi era turbulensi era yang penuh dengan gejolak, sehingga perlu dilakukan reformasi PIKR yaitu power, information, knowledge, reward. ${ }^{24}$

\footnotetext{
${ }^{23}$ Drs. Salahuddin, SH.MH, Hakim Pengadilan Agama Ambon Kelas IA, "Hasil Wawancara" Tanggal 2 Agustus 2016

${ }^{24}$ Adiwarman A Karim, Ekonomi Islam Suatu Kajian Kontemporer (Cet. III; Jakarta: Gema Insani Press, 2007), h. 149
} 


\section{Tahkím}

Vol. XIV, No. 1, Juni 2018

Dengan demikian berdasarkan tiga factor utama yang dikaji oleh peneliti terkait uraian-uraian tersebut tersebut di atas, maka dapatlah disimpulkan bahwa kendala atau hambatan yang dihadapi sekaligus menjadi kelemahannya pengadilan agama Ambon kelas IA terkait dengan persoalan menyelesaikan sengketa ekonomi syari'ah atau perbankan syariah antara lain; keadaan kesiapan sumber daya manusia para hakim masih kurang memadai, seringnya mutasi hakim di lingkungan pengadilan agama, koleksi perpustakaan di pengadilan agama secara kualitas maupun kwantitas belum memadai, hukum materiil maupun formil yang mengatur kegiatan ekonomi syari'ah belum lengkap, keengganan masyarakat beperkara di pengadilan khususnya pengadilan agama karena membutukan biaya dan waktu yanag banyak, serta kurangnya sosialisasi berbagai ketentuan-ketentuan yang mengatur ekonomi syari' ah atau perbankan syariah kepada masyarakat kota Ambon

\section{Kesimpulan}

Berdasarkan hasil penelitian tersebut, maka penulis dapat menyimpulkan beberapa poin dalam penelitian ini, sebagai berikut;

1. Secara esensial pengadilan agama Ambon kelas IA, telah siap dalam rangka menyelesaikan sengketa perbankan syariah terbukti hakim telah meyiapkan diri dengan berbagai cara; sering berdiskusi dengan sesama hakim, mempelajari aturanaturan terkait dengan ekonomi syariah mislanya; Kompilasi Hukum Islam, Kompilasi Hukum Ekonomi Syariah, Undang-Undang No 21 Tahun 2008 Tentang Perbankan Syariah dan kitab-kitab fiqhi baik itu kitab klasik maupun kitab fikhi kontemporer di satu sisi. Di sisi lain hakim pengadilan agama Kelas IA Ambon berusaha untuk mengikuti program yang dilaksanakan oleh Mahkamah Agung terkait pendidikan dan pelatihan ekonomi syariah namun belum ada yang lulus.

2. Sedangkan pelaksanaan penyelesaian sengketa perbankan syariah belum dijalankan pengadilan agama Ambon kelas IA disebabkan; keadaan kesiapan sumber daya manusia hakim masih kurang memadai, seringnya mutasi hakim di lingkungan pengadilan agama, keengganan masyarakat beperkara di pengadilan agama karena membutukan biaya dan waktu yanag banyak, serta kurangnya sosialisasi berbagai ketentuan-ketentuan yang mengatur ekonomi syari'ah atau perbankan syariah kepada masyarakat kota Ambon. 


\section{Tahkím}

Vol. XIV, No. 1, Juni 2018

\section{DAFTAR PUSTAKA}

Antonio, M. Syaifi'i. Bank Syariah Antara Teori Ke Praktek, Jakarta: Gema Insani, 2005

Arto, A. Mukti. Garis Batas Kekuasaan Pengadilan Agama dan Pengadilan Negeri : Penerapan Asas Personalitas Keislaman Sebagai Dasar Penentuaan Kekuasaan Pengadilan Agama, Jakarta : Varia Peradilan, 2000

Basir, Cik. Penyelesaian Sengkat Bank Syariah, Jakarta: Kencana 2008

Karim, Adiwarman A. Ekonomi Islam Suatu Kajian Kontemporer, Cet. III; Jakarta: Gema Insani Press, 2007

Muhammad. Bank Syariah Problem dan Prospekk Perkembangan di Indonesia, Yogyakarta: Graha Ilmu, 2005

Mujahidin, Ahmad. Prosedur Penyelesaian Sengketa Ekonomi Syariah di Indonesia, Bogor: Ghalia, Indonesia, 2010

Noeh, Zaini Ahmad. Sejarah Peradilan Agama di Indonesia, Laporan Hasil Simposium Sejarah Peradilan Agama tanggal 8 s.d. 10 April 1982 di Hotel USSU Cisarua Bogor), Bagian Proyek Pembinaan Administrasi Hukum dan Peradilan Agama, Departemen Agama RI, 1982/1983.

Perwataatmadja, Karnaen. Bank dan Suransi Islam di Indonesia, Jakarta: Prenada Media, 2005

Sjahdeini, Sutan Remy. Perbankan Islam dan Kedudukannya Dalam Tata Hukum Perbankan Indonesia, Jakarta: Pustaka Utama Grafiti, 1999

Usman, Rachmadi. Aspek-aspek Hukum Perbankan di Indonesia, Jakarta: Gramedia Pustaka Utama, 2003

Wijaya, Krisna. Reformasi Perbankan Nasional, Jakarta: Harian Kompas, 2000

\section{Undang-Undang}

Kitab Undang-Undang Hukum Perdata

Undang - Undang Nomor 7 Tahun 1989 Tentang Peradilan Agama

Undang Nomor 3 Tahun 2006 Tentang Perubahan atas Undang - Undang No. 7 Tahun 1989 Tentang Peradilan Agama

Undang-Undang Nomor 7 Tahun 1992 Tentang Perbankan

Undang-Undang Nomor 10 Tahun 1998 Tentang Perbankan

Republik Indonesia. Undang-Undang Nomor 21 Tahun 2008 tentang Perbankan Syariah, Bandung: Fokus Media, 2011. 